\title{
Decision Support System of Advisability Assessment of Partnership Funding Recipient Using Simple Additive Weighting Method
}

\author{
Yadi UTAMA ${ }^{1}$, FATHONI $^{2}$, and Ali IBRAHIM ${ }^{3} *$

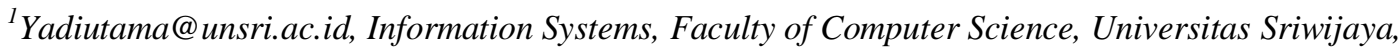 \\ Indonesia \\ ${ }^{2}$ fathoni@unsri.ac.id, Information Systems, Faculty of Computer Science, Universitas Sriwijaya, \\ Indonesia \\ ${ }^{3}$ aliibrahim@unsri.ac.id, Information Systems, Faculty of Computer Science, Universitas Sriwijaya, \\ Indonesia \\ *Corresponding author : aliibrahim@unsri.ac.id
}

\begin{abstract}
Pupuk Sriwidjaja Palembang usually distrubutes its assistance in a form of goods, and foods, or credit loans for an event or acrivity. But, the most thing that this company distributes to people around it is loan funding for those who are poor. Furthermore, choosing a candidate to fulfill requirements to receive the fund has to be performed accurately so that there is no nonperforming loan of the consumers which causes loss for the company. The best solution that the company can do is implementing Decision Support System (DSS) which is able to count all aspects. This system uses Simple Additive Weighting (SAW) which will assist the company to find the best choice of the best candidate that meet the requirements of the company. At last, this system is able to decide those who have fulfilled the requirements and have had right to get loans.
\end{abstract}

Keywords: DSS, Simple Additive Weight (SAW)

\section{Background}

As one of fertilizer company, Sriwidjaja that this kind of industry which is located in South Sumatra for more than 50 years has proven their ability and commitment to do their important jobs given by the government. A grant that is distributed by this Sriwidjaja Palembang fertilizer company usually is in the form of goods, groceries, or any kinds of credit loan to an activity or an event. But the thing that is often distributed to people around the company is loan funding for poor people. Choosing a candidate to fulfill requirements to receive the fund has to be performed accurately so that there is no non-performing loan of the consumers which causes loss for the company [1]. Therefore, a computerized decision support system is needed to be able to ease analyzing multicriteria data for the effort of helping decision making analysis of consumer who deserves the credit. Decision Support System (DSS) is one of the company's solutions to help to do decision making of which consumer who deserves the credit. This system utilizes data, model, giving an easy face-to-face user, and also combining thoughts in making a decision. Creating this DSS hopefully will sort out the unstructured problems.
A calculation method is needed to design a decision support system that is used for sorting out the problems with multi-criteria. One of the calculation mesthod used is Simple Additive Weighting (SAW). The basic concept of SAW method is to look for the last weighting value of assessment result of every alternative way from the attribute. Choosing SAW method because of the best alternative selection of many alternative existing selections is an alternative way that deserves partnership grants based on the criterias that have been determined before. The research is done to find out the weighting value for all criterias, and after that, an useful ranking process is performed to sort the choices, so that the optimal alternative can be determined which is the candidates of partnership grant.

\section{Literature}

Decision Support System is an interactive information system which provides information, modeling, and data manipulation. This system aims to assist decision making in a structured and unstructured situation that there is no one who knows how the decision should be made[4]. Furthermore, according to James O'Brien and 
George M. Marakas[2], they stated that 'Decision Support System is an information system which uses a decision model, a database, and an insight from decision maker in the modeling process which is ad hoc and interactive to achieve a specific decision made by a decision maker'.

In conducting this research, one of journals that becomes a reference is the research that was conducted by Yasni Djamain and Herlinda De Christin regarding decision support system of the recruitment of PT. PLN head office of new employees by using Simple Additive Weighting (SAW) method based on the determined criterias, which are: disciplinary, formal/informal experiences period, obeying tasks and jobs, capability, leadership, skill, work results obtained, moral and behavior, cooperation, creativity, and innovation [5]. Additionally, the research conducted by Wayan Sriwidani, Ika Purwati Ningrum, and Rahmat Ramadhan has written a journal about decision support system of employees' recruitment at PT. Sultra Inti Roda Perkasa using Weighted Product (WP) method and Simple Additive Weighting (SAW) based on the criterias: education, work experience, basic ability test, skill test, and interview test. To determine who passes to become an employee, PT. Sultra Inti Roda Perkasa used programming language of VB.NET [5]. Decision Support System is designed to support all stages of decision making starting from identifying problem; choosing relevant data; and determining approach that is used in the process of decision making; to evaluating existing alternatives selection [3].

\section{Simple Additive Weighting (SAW)}

Simple Additive Weighting (SAW) method is one of settlement method that is offered to sort out the problem of Fuzzy Multi Attribute Decision Making (FMADM). This method has functions to look for the best and the optimal alternative of many alternatives provided in a certain criteria. Furthermore, this method is commonly known as the weighted sum method. The basic concept of this method is to look for the weighted sum of perfomance rating in every alternative of all attributes ([5]. This SAW method is able to do an assessment accurately and precisely because it is based on the value of the criteria and preference weight that have been determined before. This method is needed by normalization process of decision matrix $\mathrm{X}$ to $\mathrm{a}$ scale that can be compared to all existing alternative ratings [5].

\section{Steps of SAW Completion}

There are some steps or stages to resolve a case using SAW method, which are:
Determining criterias that will be used as a reference or comparation in decision making, i.e. $\mathrm{C}_{\mathrm{i}}$.

Determining suitability rating in every alternative of every criteria.

Making decision matrix based on the criteria $\left(\mathrm{C}_{\mathrm{i}}\right)$, then performing matrix normalization based on the similarity that is adjusted to a kind of attribute (benefit attribute and cost attribute), so that normalized matrix $\mathrm{R}$ will be obtained.

The final result will be obtained from the ranking process, which is the sum of the multiplication of normalized matrix $\mathrm{R}$ with the weight vector, so that the largest value that is choosen as the best alternative $\left(\mathrm{A}_{\mathrm{i}}\right)$ as a solution can be obtained.

The formula that is intended to do this normalization is:

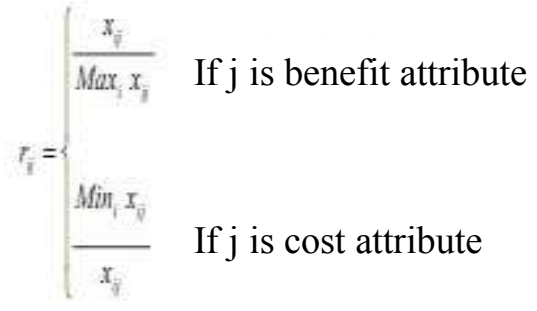

Description:

$r_{i j}=$ Normalized performance rating

$x_{i j}=$ Attribute value that every criteria has

$\operatorname{Max} x_{i}=$ Largest value of every criteria

$\operatorname{Min} n_{i}=$ Smallest value of every criteria

Benefit = If the largest value is the best one

Cost $=$ If the smallest value is the best one

Where $r_{i j}$ is a normalized performance rating of alternative $\mathrm{A}_{\mathrm{i}}$ on attribute $\mathrm{C}_{\mathrm{j}} ; i=1,2, \ldots$, $\mathrm{m}$ and $j=1,2, \ldots ., \mathrm{n}$.

Preference value for every single alternative $\left(V_{i}\right)$ is given by:

$$
V_{i}=\sum_{j=1}^{n} w_{j} r_{i j}
$$

Description:

$V_{i}=$ Ranking of every alternative

$w_{j}=$ Value of every criteria

$r_{i j}=$ Normalized performance rating value

The value of $V_{i}$ which is larger than another value indicates that the alternative $A_{i}$ is more elected.

\section{Assigning Value Weight}

Assigning value weight for every criteria based on the level of its importance, which is: 
Table 1 Value Weight

\begin{tabular}{|l|c|}
\hline \multicolumn{1}{|c|}{ Weight } & Value \\
\hline Very Good (VG) & 4 \\
\hline Good (G) & 3 \\
\hline Fair (F) & 2 \\
\hline Poor (P) & 1 \\
\hline
\end{tabular}

Assigning the value weight in Table 1 is obtained from the result of interview with superintendent of partnership PKBL that the specified values are 4, $3,2,1$. Therefore, the steps below are needed:
1. Determining criterias that will be used as a reference or comparation in decision making, which is $\mathrm{C}_{\mathrm{i}}$. The criterias that are used to determine the value given to all potential partners, which are:

Table 2 Priority Value of Every Criteria

\begin{tabular}{|l|c|c|}
\hline \multicolumn{1}{|c|}{ Criteria } & Value & Description \\
\hline Occupation & $20 \%$ & $\mathrm{C} 1$ \\
\hline Income & $25 \%$ & $\mathrm{C} 2$ \\
\hline Collateral value & $25 \%$ & $\mathrm{C} 3$ \\
\hline Number of dependents & $10 \%$ & $\mathrm{C} 4$ \\
\hline Home ownership & $20 \%$ & $\mathrm{C} 5$ \\
\hline TOTAL & $100 \%$ & \\
\hline
\end{tabular}

The priority value in Table 2 above is obtained from the determination result given by PKBL in the interview process. There are 5 specified criterias and total value when it already obtained the total sum and it must be $100 \%$, and after that, the value weight of each criteria will be determined as shown in the table below:

Table 3 Value of Occupation (C1)

\begin{tabular}{|c|c|c|}
\hline \multirow{2}{*}{ Criteria } & Criteria of Potential Partner & Value \\
\hline \multirow{2}{*}{ Occupation } & Civil Servant & 1 \\
\cline { 2 - 3 } & & 2 \\
\cline { 2 - 3 } & Trader & 3 \\
\cline { 2 - 3 } & Private Employee & \\
\cline { 2 - 3 } & & 4 \\
\end{tabular}

Based on Table 3 above with criteria $\mathrm{C} 1$, there are values that has been determined in Table 2. For example: if a potential partner fill the range "farmer", then he/she will get value 4 with the description "Very Good (SB), and so on (according to existing potential partners datas). 
Table 4 Value of Income (C2)

\begin{tabular}{|c|c|c|}
\hline Criteria & Criteria of Potential Partner & Value \\
\hline \multirow{4}{*}{ Income } & $<1,5$ million & 1 \\
\cline { 2 - 3 } & $1,5-2,9$ million & 2 \\
\cline { 2 - 3 } & 3 million - 5 million & 3 \\
\cline { 2 - 3 } & $>5$ million & 4 \\
\hline
\end{tabular}

Based on Table 4 above with criteria $\mathrm{C} 2$, there are values that has been determined in Table 2. For example: if a potential partner has an income of 4 million, then he/she will get value 3 with the description "Good (G)" and so on (according to existing potential partners datas).

Table 5 Collateral Value (C3)

\begin{tabular}{|c|c|c|}
\hline \multirow{4}{*}{ Criteria } & Criteria of Potential Partner & Value \\
\hline \multirow{3}{*}{ Collateral Value } & $<150 \%$ of loan & 1 \\
\cline { 2 - 3 } & $151-175 \%$ of loan & 2 \\
\cline { 2 - 3 } & $176-200 \%$ of loan & 3 \\
\cline { 2 - 3 } & $>200 \%$ of loan & 4 \\
\hline
\end{tabular}

Based on Table 5 above with criteria $\mathrm{C} 3$, there are values that has been determined in Table 2. For example: if a potential partner has a guarantee of more than $200 \%$, then he/she will get value 4 with the description "Very Good (VG)", and so on (according to existing potential partners datas). 
Table 6 Value of Number of Dependents (C4)

\begin{tabular}{|l|c|c|}
\hline \multirow{2}{*}{ Criteria } & Criteria of Potential Partner & Value \\
\hline \multirow{2}{*}{$\begin{array}{l}\text { Number of } \\
\text { Dependents } \\
\text { (Wife and Children) }\end{array}$} & $>10$ people & 1 \\
\cline { 2 - 3 } & $7-9$ people & 2 \\
\cline { 2 - 3 } & $4-6$ people & 3 \\
\hline & & \\
\cline { 2 - 3 } & $<3$ people & \\
\hline
\end{tabular}

Based on Table 6 above with criteria $\mathrm{C} 4$, there are values that has been determined in Table 2. For example: if a potential partner has number of dependents less than 3 people, then he/she will get value 1 with the description "Poor (P)", and so on (according to existing potential partners datas).

Table 7 Value of Home Ownership (C5)

\begin{tabular}{|c|c|c|}
\hline Criteria & Criteria of Potential Partner & Value \\
\hline \multirow{4}{*}{ Home Ownership } & Tenant & 1 \\
\hline & House Ownership Credit & 2 \\
\hline & Parents-owned & 3 \\
\hline & Home Owner & 4 \\
\hline
\end{tabular}

Based on Table 7 above with criteria C5, there are values that has been determined in Table 2. For example: if a potential partner has his/her own home, then he/she will get value 4 with the description "Very Good (VG)", and so on (according to existing potential partners datas).

Determining suitability rating in every alternative of every criteria: 
Table 8 Data of Potential Partner of PKBL Grant Recipient

\begin{tabular}{|c|c|c|c|c|c|c|}
\hline No & Name & Occupation & Income & $\begin{array}{c}\text { Collateral } \\
\text { Value }\end{array}$ & $\begin{array}{l}\text { Number of } \\
\text { Dependent }\end{array}$ & Home Ownership \\
\hline 1 & Rosda Sari, SE & Civil Servant & 3 million & $180 \%$ & 2 & Parents-owned \\
\hline 2 & Susilawati & Farmer & 4 million & $250 \%$ & 1 & Home Owner \\
\hline 3 & Masrul MB & Farmer & 5 million & $250 \%$ & 4 & $\mathrm{HOC}$ \\
\hline 4 & Muhadi & Civil Servant & 3 million & $210 \%$ & 1 & Parents-owned \\
\hline 5 & Tasrun Nazirin & Civil Servant & 6 million & $225 \%$ & 5 & Parents-owned \\
\hline 6 & Siska Widi Astuti & Civil Servant & 4 million & $190 \%$ & 4 & $\mathrm{HOC}$ \\
\hline 7 & Listiawaty & Farmer & 4 million & $250 \%$ & 0 & Parents \\
\hline 8 & Syahrul & Farmer & 8 million & $250 \%$ & 1 & Home owner \\
\hline 9 & Titin Sumarni & Trader & 4 million & $180 \%$ & 4 & Parents-owned \\
\hline 10 & Ardani Baki & Civil Servant & 2,5 million & $200 \%$ & 4 & Parents-owned \\
\hline
\end{tabular}

The datas in Table 8 above was obtained from the test results of potential partners conducted before. These datas will be used later to make suitability rating of every alternative in every criteria. For example: Susilawati as a potential partner has a data $\mathrm{C} 1=$ farmer, $\mathrm{C} 2=4$ million, $\mathrm{C} 3=250 \%, \mathrm{C} 4=1$, and $\mathrm{C} 5=$ home owner. $\mathrm{C}$ here is the specific criteria. 
Table 9 Suitability Rating of Every Alternative in Every Criteria

\begin{tabular}{|c|c|c|c|c|c|c|}
\hline $\mathrm{NO}$ & Alternative & & & Criteria & & \\
\hline & & $\mathrm{C} 1=20 \%$ & $\mathrm{C} 2=25 \%$ & $\mathrm{C} 3=25 \%$ & $\mathrm{C} 4=10 \%$ & $\mathrm{C} 5=20 \%$ \\
\hline 1 & Rosda Sari, SE & 1 & 3 & 3 & 4 & 3 \\
\hline 2 & Susilawati & 4 & 3 & 4 & 4 & 4 \\
\hline 3 & Masrul MB & 4 & 3 & 4 & 3 & 2 \\
\hline 4 & Muhadi & 1 & 3 & 4 & 4 & 3 \\
\hline 5 & Tasrun Nazirin & 1 & 4 & 4 & 3 & 3 \\
\hline 6 & Siska Widi Astuti & 1 & 3 & 3 & 3 & 2 \\
\hline 7 & Listiawaty & 4 & 3 & 4 & 4 & 3 \\
\hline 8 & Syahrul & 4 & 4 & 4 & 4 & 4 \\
\hline 9 & Titin Sumarni & 2 & 3 & 3 & 3 & 3 \\
\hline 10 & Ardani Baki & 1 & 2 & 3 & 3 & 3 \\
\hline
\end{tabular}

Table 9 has datas obtained from value weight of every criteria that is in accordance with the table of data sample of potential partners, and then the table of every criteria, and the table of value weight as well. For example: Susilawati as a potential partner has income value of 4 million, then the suitability rating will obtain the specific value.

\section{Decision Matrix Making}

According to the criteria $\left(C_{i}\right)$, and afterwards matrix normalization is conducted by based on the similarity that is adjusted to the kind of attribute (benefit attribute and cost attribute), so that normalized matrix $\mathrm{R}$ is obtained.

$X=\left|\begin{array}{lllll}1 & 3 & 3 & 4 & 3 \\ 4 & 3 & 4 & 4 & 4 \\ 4 & 3 & 4 & 3 & 2 \\ 1 & 3 & 4 & 4 & 3 \\ 1 & 4 & 4 & 3 & 3 \\ 1 & 3 & 3 & 3 & 2 \\ 4 & 3 & 4 & 4 & 3 \\ 4 & 4 & 4 & 4 & 4 \\ 2 & 3 & 3 & 3 & 3 \\ 1 & 2 & 3 & 3 & 3\end{array}\right|$

Based on the calculation result, the matrix obtained is as follows:

\begin{tabular}{|c|c|c|c|c|c|}
\hline \multirow{10}{*}{$R=$} & [ 0.25 & 0.75 & 0.75 & 1.00 & $0.75]$ \\
\hline & [ 1.00 & 0.75 & 1.00 & 1.00 & $1.00]$ \\
\hline & [ 1.00 & 0.75 & 1.00 & 0.75 & $0.50]$ \\
\hline & [ 0.25 & 0.75 & 1.00 & 1.00 & $0.75]$ \\
\hline & [ 0.25 & 1.00 & 1.00 & 0.75 & $0.75]$ \\
\hline & [ 0.25 & 0.75 & 0.75 & 0.75 & $0.50]$ \\
\hline & [ 1.00 & 0.75 & 1.00 & 1.00 & $0.75]$ \\
\hline & [ 1.00 & 1.00 & 1.00 & 1.00 & $1.00]$ \\
\hline & [ 0.50 & 0.75 & 0.75 & 0.75 & $0.75]$ \\
\hline & [ 0.25 & 0.50 & 0.75 & 0.75 & $0.75]$ \\
\hline
\end{tabular}

Matrix value above is obtained from the result of calculation normalization between criteria value divided by the largest value of all criterias of every potential partner.

The final result is obtained from the ranking process which is the sum of normalized matrix R multiplication and weight vector, so that the largest values is obtained and elected to become the best alternative $\left(A_{i}\right)$ as a solution. In this stage, the formula used is the equation 2.2 .

Weight vector $=(\mathbf{2 0 \%}, \mathbf{2 5 \%}, \mathbf{2 5 \%}, \mathbf{1 0 \%}, \mathbf{2 0} \%)$ 


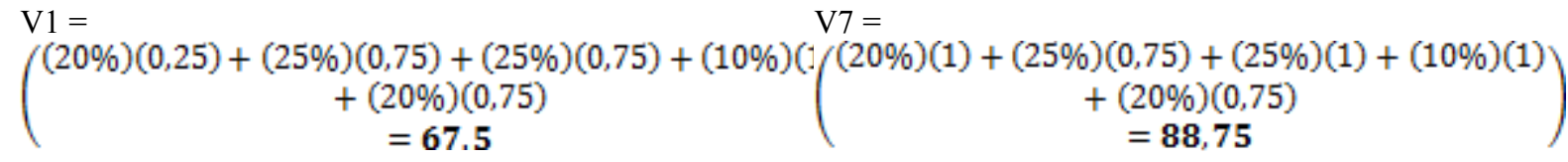

$\mathrm{V} 2=$
$\left.\left(\begin{array}{c}(20 \%)(1)+(25 \%)(0,75)+(25 \%)(1)+(10 \%)(1) \\ +(20 \%)(1) \\ =\mathbf{9 3 . 7 5}\end{array}\right) \quad \begin{array}{l}\mathrm{V} 8= \\ (20 \%)(1)+(25 \%)(1)+(25 \%)(1)+(10 \%)(1) \\ +(20 \%)(1) \\ =\mathbf{1 0 0}\end{array}\right)$ $\mathrm{V} 3=$
$\left(\begin{array}{c}(20 \%)(1)+(25 \%)(0,75)+(25 \%)(1)+(10 \%)(1) \\ +(20 \%)(0,75) \\ =\mathbf{8 1 , 2 5}\end{array}\right)$

$\mathrm{V} 9=$

$\left(\begin{array}{c}(20 \%)(0,5)+(25 \%)(0,75)+(25 \%)(0,75)+(10 \%)(0,75) \\ +(20 \%)(0,75) \\ =\mathbf{7 0}\end{array}\right)$

$\mathrm{V} 4=$
$\left(\begin{array}{c}(20 \%)(0,25)+(25 \%)(0,75)+(25 \%)(1)+(10 \%)(1) \\ +(20 \%)(0,75) \\ =\mathbf{7 3 , 7 5}\end{array}\right)\left(\begin{array}{c}\mathrm{V} 10= \\ (20 \%)(0,25)+(25 \%)(0,5)+(25 \%)(0,75)+(10 \%)(0,75) \\ +(20 \%)(0,75) \\ =\mathbf{5 8 , 7 5}\end{array}\right)$

$\mathrm{V} 5=$

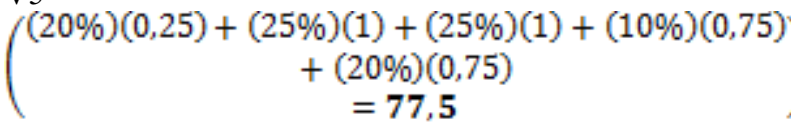

The sum results above are obtained from the multiplication result between weight vector and normalized matrix, and afterwards if the

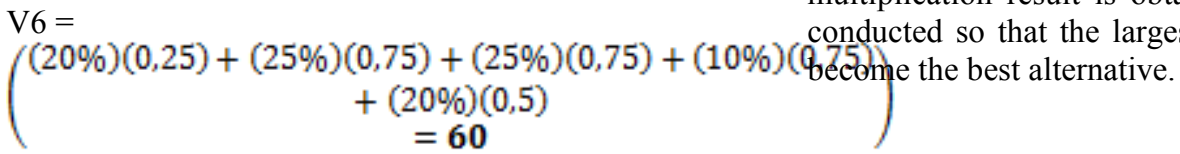
multiplication result is obtained, then the sum is

Table 10 will show the calculation result obtained by using SAW method:

Table 10 SAW Calculation Result

\begin{tabular}{|c|c|c|}
\hline No & Name & Value \\
\hline 1 & Rosda Sari, SE & 67,5 \\
\hline 2 & Susilawati & 93,75 \\
\hline 3 & Masrul MB & 81,25 \\
\hline 4 & Muhadi & 73,75 \\
\hline 5 & Tasrun Nazirin & 77,5 \\
\hline 6 & Siska Widi Astuti & 60 \\
\hline 7 & Listiawaty & 88,75 \\
\hline 8 & Syahrul & 100 \\
\hline 9 & Titin Sumarni & 70 \\
\hline 10 & Ardani Baki & 58,75 \\
\hline
\end{tabular}

Based on Table 3.10, it shows that the value is above $50 \%$, it means that they deserves PKBL partnership grant.
Afterwards the researcher sorted the datas from the largest value to the smallest value, so that it can be known which potential partners who deserve the grant. The result is shown in Table 11: 
Table 11 SAW Ranking Result

\begin{tabular}{|c|l|c|c|}
\hline No & \multicolumn{1}{|c|}{ Name } & Value & Ranking \\
\hline 8 & Syahrul & 100 & 1 \\
\hline 2 & Susilawati & 93,75 & 2 \\
\hline 7 & Listiawaty & 88,75 & 3 \\
\hline 3 & Masrul MB & 81.25 & 4 \\
\hline 5 & Tasrun Nazirin & 77.5 & 5 \\
\hline 4 & Muhadi & 73.75 & 6 \\
\hline 9 & Titin Sumarni & 70 & 7 \\
\hline 1 & Rosda Sari, SE & 67.5 & 8 \\
\hline 6 & Siska Widi Astuti & 60 & 9 \\
\hline 10 & & & \\
\hline & Ardani Baki & 58.75 & 10 \\
\hline
\end{tabular}

Based on Table 11 above, it shows that the values are above $50 \%$. It means that they deserves PKBL partnership grant.

\section{CONCLUSION}

Based on the discussion conducted, the researcher concludes that Decision Support System of advisability assessment of partnership grant recipient using Simple Additive Weighting (SAW) method can ease calculation and result alternatives with many aspects and criterias, so that it can result objective result.

\section{REFERENCES}

[1] Suhari, Yohanes, Muji Sukur, dan Sri Eniyati. 2009. Decision Support System for Credit Provision to PT. BPR Artamanunggal Abadi Mranggen. Journal of Information Technology, Universitas Stikubank Semarang, Vol. 1, No. 1 ISSN: 2085-3343.

[2] Cahyono, N. (2016, 12). Understanding Decision Support System. Retrieved from understanding-system-support-decision: http://www.noficahyono.com/2016/12/pengertia n-sistem-pendukung-keputusan.html

[3] Kusrini. 2007. Decision Support System Concepts and Applications. ADITYA, Semarang. Car on the CV. Semarang Family Car Using Analytical Hierarchical Process (AHP) Method. Journal of Information Systems, Ilmu Komputer, UDINUS Semarang.

[4]Turban, Efraim, Jay E. Aronson, dan Ting Peng Liang. 2005. Decision Support System and Intelligent System. ANDI, Yogyakarta.

[5] Rizki Chandra Kurniawan, Acun Kurniawan. 2009. Decision Support System To Assess Credit Worthiness Using the SAW Method at Bpr Artomoro Semarang, Universitas Dian Nuswantoro

[6] Wibowo, Henry. 2011. Decision Support System to Determine the Acceptance of BRI Bank Scholarships Using FMADM (Case Study: Students of the Faculty of Industrial Technology, Islamic University of Indonesia). 